Financial History Review 28.2 (202 I), pp. 205-236. (C) The Author(s), 202I. Published by Cambridge University Press on behalf of the European Association for Banking and Financial History. This is an Open Access article, distributed under the terms of the Creative Commons Attribution licence (http://creativecommons.org/licenses/by/4.0/), which permits unrestricted re-use, distribution, and reproduction in any medium, provided the original work is properly cited.

doi:I0.I0I7/So96856502100007X

\title{
Friends or foes? Brazil, the IMF and the World Bank, I96I-I967
}

\author{
CARLO EDOARDO ALTAMURA* and CLAUDIA KEDAR ${ }^{\star \star}$ \\ *Graduate Institute of International and Development Studies \\ **The Hebrew University of Jerusalem
}

\begin{abstract}
Between June 1959 and March 1964, the democratic governments of Brazilian presidents Juscelino Kubitschek (January I956 - January I96I), Janio Quadros (January-August I96I), Ranieri Mazzilli (August-September I96I) and João 'Jango' Goulart (September I96I - April I964) received no support from the World Bank (WB), which refused to fund even a single new project during this period. During this same period, and, more specifically, between July I958 and January 1965, the International Monetary Fund (IMF), the WB's twin institution, granted financial assistance to Brazil only twice: a controversial and highly conditional Stand-By Arrangement (SBA) signed in May I96I; and a non-conditional and automatically approved Compensatory Financial Facility (CFF), granted in May 1963 to compensate Brazil for the decrease in coffee prices on the international market.

This attitude towards Brazil changed significantly following the military coup of March I964. Money flowed into the country and by 1970 Brazil had become the largest receiver of WB funds and a chronic borrower from the IMF, signing two SBAs in I965, and one per year between I966 and I972. We use recently disclosed material from the International Monetary Fund and the World Bank archives to analyse the relationship of these two institutions with Brazil and to foster the debate on their political neutrality, arguing that the difference in the IMF's and especially the WB's relations with the military regime reflected, more than anything else, the existence of an ideological affinity between the parties with regards to the 'right' economic policy.
\end{abstract}

Keywords: International Monetary Fund, World Bank, Brazil, debt, authoritarianism

JEL classification: $\mathrm{F}_{33}, \mathrm{~F}_{34}, \mathrm{~N} 26, \mathrm{~N} 86$

Between June I959 and March I964, the democratic governments of Brazilian presidents Juscelino Kubitschek (January I956 - January I96I), Janio Quadros

Carlo Edoardo Altamura (corresponding author), Department of International History, Graduate Institute of International and Development Studies, Maison de la Paix P2-519, Chemin EugèneRigot 2, CH-I2I I Geneva 2I, Switzerland; email: edoardo.altamura@graduateinstitute.ch; Claudia Kedar, Department of Spanish and Latin American Studies \& Institute of History, The Hebrew University of Jerusalem, Israel; email: claudia.kedar@mail.huji.ac.il. The authors contributed equally to this article; the order of their names was alphabetically determined. This article is part of a research project on international finance and authoritarian regimes in Latin America generously supported by the Swiss National Science Foundation, Ambizione grant no. PZ00PI_I79892 / I, with the assistance of Dr Kim Seung-Woo. This research was supported by the Israel Science Foundation, grant no. 63 I/I 9 . The authors wish to thank the two anonymous referees for their insightful comments and suggestions. 
(January-August I96I), Ranieri Mazzilli (August-September I96I) and João 'Jango' Goulart (September I96I - April I964) received no support from the World Bank (WB), which refused to fund even a single new project during this period. The Bank insisted that this was due to the country's inability to keep inflation at bay, devise credible projects and stabilise the exchange rate. During this same period, and, more specifically, between July I958 and January I965, the International Monetary Fund (IMF), the WB's twin institution, granted financial assistance to Brazil only twice: a controversial and highly conditional Stand-By Arrangement (SBA) signed in May I96I; and a non-conditional and automatically approved Compensatory Financial Facility (CFF), granted in May I963 to compensate Brazil for the decrease in coffee prices on the international market.

This attitude towards Brazil changed significantly following the military coup in March I964. The coup, which deposed the democratic government of the leftist President Goulart, established a right-wing military dictatorship that remained in power until I985. Soon after the coup, high-ranking officials of the IMF and the WB began visiting the country regularly and established a collaborative relationship with Brazil's economic team. Money flowed into the country and by I970 Brazil had become the largest receiver of WB funds and a chronic borrower from the IMF, signing two SBAs in I965, and one per year between I966 and I972.

Although the IMF and the WB are, by their own rules, committed to 'political neutrality' the above description of events compels the following questions: To what extent was this change in lending to Brazil on the part of the IMF and especially the WB a result of the shift from democracy to military rule and/or from a leftist to a right-wing regime? Were the IMF and the WB 'politically neutral' when approving or rejecting Brazil's loan requests?

Drawing on a large corpus of historical evidence from the archives of the WB and the IMF (Washington, DC), disclosed at the authors' request, this article seeks to examine the changing relationship between the Bretton Woods institutions and Brazil from I96I, the beginning of Goulart's presidency, until the end of the Castello Branco dictatorship in I967. In doing so, it positions the military coup as a privileged vantage point from which to assess, on the one hand, whether the WB and the IMF preferred to collaborate with right-wing military rulers over democratic presidents, and, on the other hand, the extent to which Brazil's military regime was more eager than democratic administrations to work with both institutions. Our main argument is that the difference in the IMF's and especially the WB's relations with the military regime reflected, more than anything else, the existence of an ideological affinity between the parties with regards to the 'right' economic policy. Notwithstanding their alleged 'political neutrality', it seems that the economic policies and measures required by the Fund and Bank as crucial conditions to lending could have been carried out more fully by a right-wing authoritarian regime.

Since their foundation at the Bretton Woods Conference of I944, the IMF and the WB have been expected to avoid political considerations in their dealings with member states. Article IV Section Io of the WB Articles of Agreement states: 'The 
Bank and its officers shall not interfere in the political affairs of any member; nor shall they be influenced in their decisions by the political character of the member or members concerned. Only economic considerations shall be relevant to their decisions, and these considerations shall be weighed impartially.' Likewise, the IMF established three principles that were intended to direct its actions: universality and equality of treatment, which imply that the IMF should not discriminate among countries, and political neutrality, which refers to the IMF's self-imposed non-discriminatory practices between the different countries and regarding the various regimes within each member state (Guitián I992, pp. I8-I9).

However, the historical evidence analysed here indicates that both the IMF and the WB used this 'political neutrality', more than once, as a cover that enabled them to present as technical and unbiased the fact that they behaved differently in their dealings with different regimes. Between 1959 and I964, rather than ignoring warning signs regarding Brazil's economy, as they were later to do under Castello Branco's regime, both the IMF and the WB used every minor or major 'neutral' economic problem as a pretext to refuse lending to the country. Furthermore, even if the two institutions were indeed 'neutral' in the sense that they had no a priori preference for any particular type of regime, one cannot deny that the implementation of the belt-tightening measures they requested in order to unlock their credit were more suited to and easily implemented by a repressive military regime than they were by a left-wing democratic administration whose main base of support (the workers) were the most affected by these same measures.

The IMF and the WB were not alone in providing financial assistance to the dictatorship. Under the shadow of the Cold War, the United States viewed the new regime as a more sympathetic interlocutor than the populist administrations of Vargas and Goulart or of Kubitschek, the main promotor of the Operation Panamerica (Amicci 2012; Sewell 2016, pp. I05-I0). Between I960 and I966, Brazil received about US $\$ 2.5$ billion in foreign aid. ${ }^{1}$ In 1965 alone, it received around US\$650 million (3 per cent of Brazil's I964 GDP) from the Inter-American Development Bank, the United States Agency for International Development (USAID) and the Export-Import Bank (Eximbank) (Ribeiro 2006).

The analysis of Brazil's relations with the IMF and WB contributes to our understanding of several fields that have heretofore been surprisingly understudied. To begin with, despite the geopolitical and economic importance of Brazil in Latin America, no historical study has systematically analysed the international economic relations of the military regime or its ties with the international financial institutions (IFIs). The few studies that focus on Castello Branco's foreign relations tend to overlook foreign finance (Simoes 20I0). Recently, scholarship has begun to address the complex interactions between commercial banks, IFIs and authoritarian regimes in Latin America. Carlo Edoardo Altamura, Raul García-Heras and Claudia Kedar

1 'Domestic capital main source of development funds', Brazilian Bulletin, 22(467), March I966. 
have all examined different facets of the financial relations of authoritarian regimes in Latin America. Kedar has carried out extensive analyses of the relationship between the WB and the Argentine dictatorship of the I970s (Kedar 20I9a, 2019b) and between the WB, the IMF and Pinochet's Chile (Kedar 20I7, 2018). García-Heras has concentrated on the international financial relations of the Argentine military junta (Garcia-Heras 20I8a, 20I8b), while Altamura has focused on European commercial banks and their activities in Latin America (Altamura 2020; Altamura and Flores 2020). With regards to Brazil, however, studies are few, especially ones that focus on the post-I964 period. This is despite the fact that the dictatorship's dependency on foreign lending and the importance of economic growth for the legitimation of the regime looms large in academic publications (Frieden I987; Bethell and Castro 2008). In his seminal work on the economics of Castello Branco's presidency, Thomas Skidmore (I978 and I988) stressed that his years in power were crucial for the establishment of the so-called 'Brazilian model' - stabilisation through relatively orthodox monetary and fiscal policies, compression of real wages, maximum access for foreign investors, and resort to a modified form of indexation to neutralise factor price distortions caused by inflation. Yet still, a definitive examination of the issue has yet to be carried out.

Also beginning to emerge is scholarship on Brazil's contemporary economic history. Felipe Loureiro, for example, has published extensively on the Quadros and Goulart periods (Loureiro 2010, 20I7). Part of his publications focus on the independent foreign policy that both presidents sought to follow, in particular vis-à-vis Washington, from the launching of the Alliance for Progress in I96I, and onwards (Loureiro 2OI4). Loureiro shows that until mid I962, the US adopted a somewhat moderate line towards Goulart, including loans within the framework of the Alliance for Progress. However, Goulart's increasingly defiant stance towards Washington ultimately led to the freeze of financial aid from the US government, the IMF and the WB.

Another significant issue that still remains understudied is the so-called stance of 'neutrality' assumed by the IMF and the WB. Relevant scholarship tends to question the actual capacity of either institution to act neutrally (Swedberg I986; Thacker I999; Barro and Lee 2002). Research tends to emphasise the link between US policies and the IMF's and Bank's decisions - a link that leads to the somewhat inevitable politicisation of their lending. Due to the adoption of a weighted voting system, the United States, the member state with the highest quota and the strongest voting power in both institutions, has always been the only member state with a de facto veto power on the Fund's and Bank's Executive Boards. Sarah Babb (2009), for example, examines the tension between the US Treasury and US Congress over the issues of Washington's policies towards the WB. Catherine Gwin (I997) maintains that the US government and US-based non-governmental actors sought to influence WB policy only when US strategic interests were threatened. While most publications conclude that the major donors (United States, Britain, France, Japan and Germany) do have an impact on who received IMF and WB aid, and how much they received (Frey \& Schneider I986; Peet 2003; Andersen, Hansen \& Markussen 2006; Fleck \& 
Kilby 2006; Woods 2006), others assert that these institutions are more sensitive to the economic needs of recipient states than to the strategic interests of donors (Burnside $\&$ Dollar 2000). Other scholars emphasise the autonomy of the two institutions, suggesting that they were able to advance their own policies (Staples 2002; Helleiner 20I4). Recently, scholars have begun to examine the IMF's and WB's 'neutrality' from the perspective of the member states. It has been suggested that when national policy paradigms fit with the policy paradigms of the IMF and WB, national actors tend to perceive both institutions as more impartial than politically biased (Heinzel et al. 2020).

By closely examining the attitude of the IMF and WB towards the governments of Brazil before and after the coup of I964, this article seeks to fill part of this glaring historiographical vacuum. With regards to the WB, projects submitted by Brazil before the coup were systematically rejected on economic grounds, as the economic policies of the democratic governments were deemed ineffective in controlling inflation, labour demands and fiscal deficits. Once the military government came to power, the WB actively supported the new economic plan (Plano de Ação Econômico do Governo, PAEG) of planning minister Roberto Campos and finance minister Otávio Gouveia de Bulhões. The IMF, by contrast, was more flexible than the Bank and found ways to remain active in Brazil regardless of the nature of the regime in power. This does not mean, however, that it treated all the Brazilian regimes equally.

The article is divided into six sections. As IMF loans tend to be a precondition for WB lending, Sections II and III focus on Brazil's relations with the IMF before and after the coup. Sections IV and V reconstruct Brazil's relations with the Bank in the same period, and Section VI provides concluding thoughts and observations.

\section{II}

Brazil signed its first SBA in July I958, during the presidency of Kubitschek. The second SBA, worth US\$I60 million, was signed in May I96I, by President Quadros (Amicci 20I2; Loureiro 2013, 20I4). ${ }^{2}$ Two months later, due to Brazil's non-compliance with the terms of the agreement, the IMF unilaterally interrupted the SBA. This interruption initiated a lending break that lasted throughout the whole presidency of Goulart who, from the start, was perceived as the heir of Vargas's populism and therefore remained under the suspicious scrutiny of conservatives within military and civilian circles. To this should be added the traumatic manner in which Goulart assumed the presidency following Quadros's sudden resignation, as well as the diminished power that was left in his hands by the Congress, ${ }^{3}$ which

2 EBS/6I/62 Supplement 2, 'Brazil - Stand-By Arrangement', I 7 May I96I (ref. 223898, IMF Archives, henceforth IMFA).

3 In September I96I, Brazil's Congress established a parliamentary system in which Goulart's cabinet was accountable to the Congress and not directly to him. 
augmented doubts already festering in the halls of the IMF and the WB regarding the administration's ability to implement a coherent economic plan and comply with its international commitments (Ramírez 2012, p. 257). ${ }^{4}$ This break, in which a small CFF granted in May I963 was the only exemption, ended in January I965, when the IMF approved an SBA to Castello Branco's dictatorship. In fact, between 1965 and 1972 the IMF granted Brazil's dictatorship eight consecutive SBAs, and an additional three between I 983 and I985. Not only did the IMF intensify lending to Brazil after the coup, but, following a request from Otávio Bulhões (Brazil's governor to the IMF and WB), Rio de Janeiro hosted the I967 annual meeting of the board of governors of the IMF and the WB, thus indicating a more than symbolic seal of approval of the dictatorship on the part of the Bretton Woods institutions.

The IMF and WB were not alone in refusing financial support to Goulart's administration, mainly because the US government and private lobbies opposed what they perceived as the administration's ties with communists and radical labour unions, as well as Goulart's independent foreign policy (Weis I993, ch. 6; Rabe I999, pp. 64-7, I96-7). This was by no means unusual. US-based institutions often used their financial assistance as leverage to persuade their borrowers to adopt 'correct' policies (Kofas 2002, ch. 7; Kedar 2013, chs. 3 and 5). Furthermore, although the IMF did not grant any SBA to Goulart, his team had to deal with the commitments assumed by previous administrations. For instance, in March I962, Walter Moreira Salles, Goulart's minister of finance, sent a letter to Per Jacobsson, the IMF's managing director (I956-63), requesting a postponement of the repurchase equivalent of US\$2O million scheduled for 3 I March to September $1962.5^{5}$ Whereas the IMF staff felt that Brazil's policy would not curb inflation or solve the budget deficit, it recommended that the EB (executive board) approve the request. ${ }^{6}$ It believed that Brazilian technocrats (unlike Brazil's government) were 'fully competent to evolve an effective program' and were 'fully aware of the need to bring the Brazilian inflation under control and to strengthen the balance of payments'. In August I962, finding itself still unable to meet IMF financial demands, Brazil formally requested the postponement of its obligations to the Fund. ${ }^{8}$

On I2 December I962, Jorge del Canto (director of the IMF's Western Hemisphere Department, WHD) informed Frank Southard Jr (IMF deputy

4 Memorandum, managing director to Bicalho, 'Brazil - Stand-By Arrangement', I9 July I96I, Brazil Country Files, Immediate Office Sous-fonds, WHDAI, box 32, folder I (I96I), file: Brazil (I959-6I), IMFA.

5 Letter, Moreira Salles to Per Jacobsson, March I962 (no day indicated), Brazil Country Files, Immediate Office Sous-fonds, WHDAI, box 33, folder 2 (I962), file: Brazil (I962-4), IMFA.

6 Del Canto, Friedman, Finch, Sacchetti and Guenther to managing director, 'Discussions with the Brazilian Mission', 30 March I962, Brazil Country Files, Immediate Office Sous-fonds, WHDAI, box 33, folder 2, file: Brazil (I962-4), IMFA.

7 Ibid.

8 Confidential memorandum, 'Brazil - Request for postponement of repurchase', August I962, Brazil Country Files, Immediate Office Sous-fonds, WHDAI, box 33, folder 2, file: Brazil (I962-4), IMFA. 
managing director) about an informal meeting he had had with a 'Brazilian friend' of the Fund, Proença de Gouvea, head of the Exchange Department of the Banco do Brasil. Del Canto intended to visit Rio to meet officers of the Banco do Brasil and other '[IMF] friends at the Ministry of Finance' for 'an informal appraisal of the situation'. $\mathrm{He}$ reported that according to Proença, the Brazilian government was working on a stabilisation plan and that it would request a Fund mission to discuss it. In order to make this plan politically acceptable, Proença argued, it would have to be presented together with a development plan. ${ }^{10}$ Proença explained that although in mid I962 Brazil's balance of payments was 'very bad', it had since improved. He stressed that most difficulties were attributed to heavy repayments against foreign indebtedness. ${ }^{11}$ Despite Proença's optimism, the WHD estimated that the deficit, which stood at US\$I 22 million, would worsen mainly due to a 50 per cent increase in government salaries and to the application of new subsidies on rice and beans which the IMF disapproved. In any case, under the coordination of minister of planning Celso Furtado, Goulart launched in December I962 the Triennial Plan for Economic and Social Development or Plano Trienal (1963-5) - a stabilisation plan that sought to implement many of the IMF's recommendations. This plan recognised two major problems in Brazil's economy. The first was the deficit of the federal government. The second was the country's chronic inability to import goods, which required permanent adjustments in the internal offer and currency devaluations (Bastian 2OI3). The ultimate goal of the plan was to stabilise the economy at an inflation rate of Io per cent by 1965 without prejudicing economic growth. In this sense, the plan eschewed a purely orthodox shock therapy in favour of a gradualist or 'eclectic' approach (Fonseca 2004).

Despite, or probably because of, the eclectic nature of the plan, the Plano Trienal was harshly criticised on both the right and the left. Trade unions saw it as caving in to Washington and the more conservative sectors of Brazilian society. Industrialists, who had initially supported the plan, grew increasingly dissatisfied with the lack of controls on wages (Almeida 20IO). The plan was abandoned in July i963 (Loureiro 20 Iо, pp. I09-43).

In February 1963, Brazil's government was at risk of defaulting on its foreign debt payments. In mid March I963, minister of finance San Tiago Dantas travelled to Washington to negotiate a US aid package in what scholars recognised as Brazil's 'last chance to save democracy' (Loureiro 2013). Dantas requested an ambitious package totalling US\$839.7 million. The negotiations were particularly difficult due to the US government's fear of communist infiltration in Goulart's administration (Loureiro 20I3). Yet obtaining external credits was an essential part of the Plano

9 Del Canto to Southard Jr, 'Brazil', I2 December I962, Brazil Country Files, Immediate Office Sous-fonds, WHDAI, box 33, folder 2, file: Brazil (I962-4), IMFA.

${ }^{10}$ Radford to Del Canto, 'Brazil - Minutes of meeting with Mr Gouvea', I I December I962, Brazil Country Files, Immediate Office Sous-fonds, WHDAI, box 33, folder 2, file: Brazil (I962-4), IMFA. 11 Ibid. 
Trienal, which estimated the financial needs for the I963-5 period at US\$I.5 billion. Without external support, any effort to stabilise prices was doomed to fail as the only two options open to Goulart's government were either to devalue the exchange rate or, alternatively, to contract domestic demand (Bastian 2013, p. I 59).

In order to avoid a default, the US provided immediate assistance totalling US\$84 million and a further much larger loan of US\$3 I 4.5 million pending agreement with the IMF, the WB, Western European countries and Japan. While in Washington, Dantas asked to meet Per Jacobsson and Southard to discuss a postponement of the US\$26.5 million repurchases that were due in March I963. ${ }^{12}$ While referring to a potential SBA, Del Canto confirmed that Brazil was eligible for an SBA of US \$I I7.6 million. He added that there was a shortfall in coffee exports in I962 that was attributable to circumstances beyond Brazil's control, thereby making Brazil eligible for IMF assistance under the new compensatory financing policy (CFF) established in 1963. Del Canto considered that a new SBA could be justified if a satisfactory plan [was] worked out between the Fund and Brazil and effective implementation of such a plan [was] insured by Brazil ....' 13

On 2 I March I963, Per Jacobsson wrote to Dantas that the Fund was impressed by Brazil's determination to design a stabilisation plan. ${ }^{14} \mathrm{He}$ stressed, however, that Brazil still had to reduce the operating deficits of the railways, merchant marine and post office, and that subsidies formerly provided could not be reintroduced. He added that emergency measures had to be taken, including reductions in the subsidies to state agencies, increases in tax revenues, the imposition of a new exchange tax and the formulation of a new coffee policy. The Fund recommended establishing a realistic and stable exchange rate and encouraging larger inflows of private capital in order to avoid increases in Brazil's short and intermediate-term external debt. ${ }^{15}$ Undoubtedly, the Fund's requests, especially the elimination of subsidies and a contractionary wage policy that implied dropping real wages, posed a harsh political challenge to Goulart as they would negatively affect the social groups to which he was most committed. Under these circumstances, Bicalho informed Del Canto that he would accept a Fund mission to finalise elaborating the stabilisation programme but only after mid April in order to give the authorities time to move the exchange rate to $\mathrm{Cr} 600$ per US dollar and firm-up the wage increase to 40 per cent. ${ }^{16}$ This postponement seems to imply that even when Goulart's administration was prepared to compromise with the IMF, neither Bicalho nor Del Canto wanted to have the

12 Confidential memorandum, Del Canto to Per Jacobsson and Southard, I4 March I963, Brazil Country Files, Immediate Office Sous-fonds, WHDAI, box 33, folder 4, file: Brazil (I962-4), IMFA.

13 Ibid.

14 Aide memoir, 2 I March I963, Brazil Country Files, Immediate Office Sous-fonds, WHDAI, box 33, folder 4, file: Brazil (I962-4), IMFA.

15 Ibid.

16 Del Canto to Southard, 'Discussion with minister of finance of Brazil', 2 I March I963, Brazil Country Files, Immediate Office Sous-fonds, WHDAI, box 33, folder 4, file: Brazil (I962-4), IMFA. 
IMF mission appear to be associated with the implementation of controversial austerity measures.

Del Canto's new mission stayed in Brazil between 8 and 29 May I963, during which time labour demonstrations demanding land reform also demanded that Goulart cease talks with the IMF mission. ${ }^{17}$ Although Del Canto doubted that Brazil would adopt a programme that could justify an SBA, he recommended continuing to maintain a dialogue with Brazilian authorities. ${ }^{18}$ On 5 June I963, the EB approved a CFF worth US $\$ 60$ million to Brazil due to export shortfalls. ${ }^{19}$ It was thus under Goulart's administration that Brazil became the first member state to receive a CFF (Boughton 20I2, pp. 2 I6-I7). Significantly less controversial than an SBA, the CFF constituted a politically more acceptable way of maintaining IMF-Brazil cooperation, especially at times of ideological disagreement between the parties. The CFF, to be sure, constitutes a kind of emergency aid which not only provides the country part of the sums it needs to solve a temporary crisis, but also sends a green light to other creditors and international markets. It is worth noting that Salvador Allende (1970-3), the socialist president of Chile, was also granted three CFFs (Kedar 20I5, pp. 7I7-47). In any case, the lack of new SBAs served as a pretext for the US administration to adopt a hard line towards Goulart's regime, including non-lending and, ultimately, supporting the coup (Loureiro 20I4, pp. 344-6).

In summary, although the IMF disagreed with Goulart's economic policy and had serious doubts about his ability to deal with the social and political tensions in Brazil, it strove to avoid an open dispute by following the same conciliatory line that it tended to adopt when dealing with other populist and left-wing leaders in the region, such as Salvador Allende and Juan Perón in the I970s. Determined to help Brazil avoid a default on its foreign debt, including debts owed to the Fund, it granted Goulart's administration a non-conditional CFF, which by no means implied that the IMF favoured Goulart's regime. The CFF, in turn, allowed Goulart to access IMF funds without taking what he feared were unacceptable political risks. Thus, it seems that the pragmatism that characterised IMF-Brazil relations during Goulart's presidency was an expression of, and facilitated by, the IMF's 'political neutrality'. On the one hand, the IMF did not provide significant financial support to a government that did not fully adopt its policy prescriptions, thereby securing the IMF's prestige as a neutral and responsible lender. On the other hand, based on 'pure' economic criteria, it granted Brazil a CFF that did not require any policy reform. Simply put, the IMF found a 'neutral' balance between its fundamental disagreements with Goulart's economic policy and its determination to help Brazil avoid a deeper economic crisis.

17 Foreign radio broadcasts, 'Thousands rally for new land reforms', 27 May I963, Brazil Country Files, Immediate Office Sous-fonds, WHDAI, box 33, folder 4, file: Brazil (I962-4), IMFA.

18 Del Canto to Southard, 'Brazil - Report on Article XIV consultations mission (May 8-29)', 3 I May I963, Brazil Country Files, Immediate Office Sous-fonds, WHDAI, box 33, folder 4, file: Brazil (I962-4), IMFA.

$19 \mathrm{EBM} / 63 / 29,5$ June I963, ref. 269835, digital doc. I 80429. IMFA. 
Brazil, for its part, used the IMF's 'neutrality' to its own benefit as it allowed Goulart to have his cake and eat it too, namely, to ignore most of the IMF's policy advice but benefit from its non-conditional financial assistance.

\section{I I}

From his first day in office, President Goulart aroused the suspicions of Brazil's right-wing and conservative elites. Under the shadow of the Cold War, his strong ties with organised labour and his defiant stand towards Washington convinced the US to support a coup to depose him. Soon after the coup, on 9 April I964, the Supreme Revolutionary Command (SRC) composed of the commanders-in-chief of all military services, issued the First Institutional Act (AI-I) - the first of many steps aimed at purging the political system. The SRC immediately cancelled the mandates of 40 congressmen, fired I 22 officers from the military, and suspended for ten years the political rights of IOO politicians and 'subversive elements' including union leaders and intellectuals (Stepan I97 I, pp. I23-4). On I I April Congress ratified the appointment of Castello Branco to serve as president for the remainder of Goulart's term. Four days later, he assumed the presidency, vested with emergency powers. Although he intended to permit limited political activities and transfer power to a civilian president in I966, political setbacks in important states and pressure coming from hard-liners, including General Artur da Costa e Silva, led Castello Branco to adopt a more authoritarian approach. Thus, on 27 October I965 he issued AI-2. This second act established indirect elections for the presidency; intervened with the composition of the supreme court; and abolished all traditional political parties, establishing in their stead a bipartisan system composed of the National Renewal Alliance (ARENA) and the Brazilian Democratic Movement (MDB). It also extended Castello Branco's term to I967 (Skidmore I988, pp. 45-9). As Roberto Campos, Castello Branco's minister of planning, stated in September I967, the postponement of the elections that were originally scheduled for I966 also had economic motivations, since the stabilisation and development plans launched by the military regime were not expected to have visible effects before I970. Moreover, as Campos argued, the military believed that no civilian leader would have the power, let alone the will to implement a stabilisation policy (Stepan I97I, pp. 2I7-I8). The repressive character of Brazil's military regime became more evident under Costa e Silva. On I 3 December I968, he issued AI-5, which permitted the military to close Congress, enabled the president to rule by decree, allowed the military to suspend any citizen's political rights for Io years and gave the military the power to dismiss public employees on all levels of government. AI- 5 also suspended the right to habeas corpus, permitted trials before military tribunals and reinstated the death penalty. In the coming months, new decrees further curtailed democratic principles: all scheduled elections were cancelled and strict censorship was implemented over cultural mediums and the press (Guerchon I97I, pp. 265-9; Skidmore I988, pp. $8 \mathrm{I}-4$ ). 
In contrast with deposed president Goulart, Castello Branco adopted a pro-US stance. This included breaking diplomatic ties with Cuba in I964, supporting the US invasion of the Dominican Republic in I965, and publicly celebrating US economic and political achievements. The Lyndon Johnson administration recognised Brazil's military regime two days after the coup and that same day, Johnson promised to augment US financial assistance to Brazil (Simoes 20IO, pp. 4I-2). As ties with the US administration improved, IMF missions and loans to Brazil multiplied.

The first IMF mission to the military regime, led by David Finch and Herbert Zassenhaus (WHD), visited Rio from 5 to 20 May $1964 .^{20}$ They met, among others, Otávio Gouveia de Bulhões (minister of finance), Roberto de Oliveira Campos (minister of planning and coordination and the main architect of the Governmental Economic Plan of Action) and Luis Moraes Barros (president of the Central Bank). Although the new economic programme was still being worked out, Brazilian authorities explained that they sought to restore the pre-I962 rate of economic growth, curb inflation and overcome the chronic budgetary deficit. They intended to raise taxes and tariffs, eliminate subsidies and liberalise the I962 law on the remittance abroad of earnings from foreign capital. One can imagine how satisfied the mission was to learn that the military regime intended to implement 'correct' policies. Although the mission's report was overly technical, a comment regarding the 'widespread understanding that substantial changes have to take place', in particular regarding 'intolerable inflation rates', led the staff to claim that, contrary to deposed President Goulart, 'the new authorities, armed with extraordinary powers, [were] therefore faced with an opportunity to take decisive action' ${ }^{21}$

The foreign debt constituted one of Brazil's most urgent economic problems. Maturing debts totalled about US $\$ 3.5$ billion but the annual exports hardly reached $\$$ I.3 billion. $^{22}$ Under these circumstances, meetings were held in Paris during March-July I964, between Brazil's representatives and ten major creditor countries: Austria, Belgium, France, the Federal Republic of Germany, Italy, Japan, the Netherlands, Switzerland, the UK and the US. Representatives of the IMF, the WB and the OECD were also present. The parties agreed to refinance payments on credits due in 1964 and $1965 .{ }^{23}$ In June, the US granted Brazil a US\$50 million credit and Ambassador Gordon promised additional funds through the Alliance for Progress (Simoes 20Io, p. 44).

In late July, John Bullitt, assistant secretary of the Treasury and US executive director to the WB, offered a lunch at the WB for representatives of the State Department, the WB and the IMF. ${ }^{24}$ Discussions focused on Brazil's development

${ }^{20}$ SM/64/27 Supplement I - 'Brazil - I963 Article XIV consultations', I June I964, Ref.2680 I7, digital doc. I66484, IMFA.

21 Ibid.

22 EBM/64/29, 8 June I964, Ref. 267475, digital doc. I80340, IMFA.

23 EBS/64/I2 I, 'Brazil - Debt renegotiation: March-July I964', I 3 July I964, IMFA.

24 Confidential office memorandum, Del Canto to Southard Jr, 'Brazil', 29 July I964, Brazil Country Files, Immediate Office Sous-fonds, WHDAI, box 33, folder 6, file: Brazil (I962-4), IMFA. 
plan. Del Canto expressed willingness to soon start lending to Brazil. The WB representatives, by contrast, stressed that they would resume working in Brazil only in October and that no financial assistance should be expected before March 1965. When Bullitt asked about a possible joint WB-IMF mission to Brazil, Del Canto responded that the IMF would prefer two parallel missions. Initially, the WB agreed with Del Canto. ${ }^{25}$ The State Department representatives then asked about the timing of the IMF's negotiations for an SBA. Del Canto answered that Brazil would not be ready to negotiate before October and stated: 'we all agree that the new group is well-intentioned; they are our friends and they deserve full sympathetic consideration', ${ }^{26}$ thus explicitly recommending adopting a sympathetic attitude towards the military authorities. Revealing a sense of competition vis-à-vis the WB he stressed: 'in view of the large Bank mission [to Brazil] we need to reaffirm our expertise knowledge in our own field and thus hope to have the Bank rely on our work in the financial field'. ${ }^{27}$

On 20 October 1964, Del Canto participated in the Inter-American Committee for the Alliance for Progress (CIAP) review of Brazil. He first praised Minister Campos, 'a long-standing friend of the Fund' ${ }^{28}$ Then, he applauded the military regime because it was 'more aware than many previous Brazilian governments of the urgency to combine a strong economic development policy with a determined attack on the problem of inflation' and because it was 'engaged in the execution of a comprehensive plan of economic and social action'. Del Canto also referred to the need to curb inflation and to improve the balance of payments. He added that the Fund was not yet ready to make decisions, but an IMF mission was already in Brazil. $^{29}$

Del Canto's optimism was short-lived. In late November I964, while heading a mission to Brazil, he updated Schweitzer about his meetings with Bicalho, Campos and Bulhões. ${ }^{30}$ He argued that he was careful not to give the Brazilians the impression that the IMF favoured granting an SBA under the existent economic situation. However, the Brazilians insisted that they needed an SBA because they were negotiating loans with the US government and needed 'the [IMF's] green light'. Del Canto concluded that 'unless [the IMF] reach a clear and enforceable agreement on exchange rate policy and a program to liquidate commercial arrears, it would be

25 Ibid.

26 Ibid.

27 Confidential office memorandum, Del Canto to Southard Jr, 'Mission to Brazil', 30 July I964, Brazil Country Files, Immediate Office Sous-fonds, WHDAI, box 33, folder 6, file: Brazil (I962-4), IMFA.

28 'Statement of Del Canto on Brazil', 20 October I964, Brazil Country Files, Immediate Office Sous-fonds, WHDAI, box 34, folder I, file: Brazil (I964-5), IMFA.

29 Ibid.

30 Confidential office memorandum, Del Canto to managing director, 'Nature of visit to headquarters', 23 November I964, Brazil Country Files, Immediate Office Sous-fonds, WHDAI, box 34, folder I, file: Brazil (I964-5), IMFA. 
absolutely impossible for the management even to consider the idea of a stand-by'.31 Following this update, Schweitzer wrote to Campos that if a satisfactory agreement with the mission was reached, Del Canto would assist him in drafting a letter of intent towards an SBA. ${ }^{32}$ Del Canto, it appears, was not the only IMF official who was keen to resume lending to Brazil.

The first economic plan of the regime, the PAEG, assumed that inflation, which had reached around 90 per cent in I964, was the main obstacle to development. The plan stressed the need to restore economic growth to the pre-I962 period; to fight the inflationary process in order to bring inflation under control by I966; and to fight balance of payment deficits that were endangering the continuity of the development process by creating bottlenecks in import capacity (Lara Resende I982). According to the Plan, and in line with the IMF's monetarist precepts, inflation was primarily caused by excess demand. Excess demand, in turn, derived from public sector deficits, excessive credit to the private sector and wage increases that were higher than the increase in productivity rates, i.e. cost inflation (Skidmore I978, p. I 54; Bastian 20I3, p. I46). Interestingly, the PAEG had more in common with the Plano Trienal than one would assume. Under an orthodox façade, the PAEG shared with the Plano Trienal a gradualist approach, seeking to lower inflation without prejudicing economic growth. Further, monetary growth was expected to reach 70, 30 and I5 per cent respectively in I964, I965 and I966 (Lara Resende I982, p. 76; Bastian 2013). Both plans targeted an inflation rate of Io per cent by the last year of their plans. On the fiscal side, the PAEG expected the federal government to reduce all non-priority expenditures; and increase revenues via a reformed fiscal system and a new market for public debt with the creation of the Obrigação Reajustável do Tesouro Nacional (ORTN). On the monetary side, the PAEG sought to limit the public deficit and control credit to the private sector (Bastian 2013, p. I48). A significant difference between the two plans, however, was the emphasis placed by PAEG's policymakers on the control of wages in order to break the inflationary spiral (Fishlow I974; Lara Resende I982), something Goulart was unable to do. As a result of the new wage and labour policies, the real minimum wage between February I964 and March I967 dramatically decreased (Figure I).

Together with the compression of wages (Lara Resende I982, pp. 803-4), there was a visible change in the concentration of income: if in 1960 the income shares of the top 5 per cent of the population was 27.69 per cent, in I970 it was 34.86 per cent. By contrast, the income shares of the bottom 50 per cent decreased from I7.7 I per cent in I960 to I4.9I per cent in I970 (Lara Resende I982, p. 804). The Gini coefficient increased from 0.49 to 0.56 between 1960 and I970 (Fishlow I974, p. 33). A final but crucial difference between the Plano Trienal and the PAEG was the very

31 Ibid.

32 Schweitzer to Campos, 25 November i964, Brazil Country Files, Immediate Office Sous-fonds, WHDAI, box 34, folder I, file: Brazil (1964-5), IMFA. 


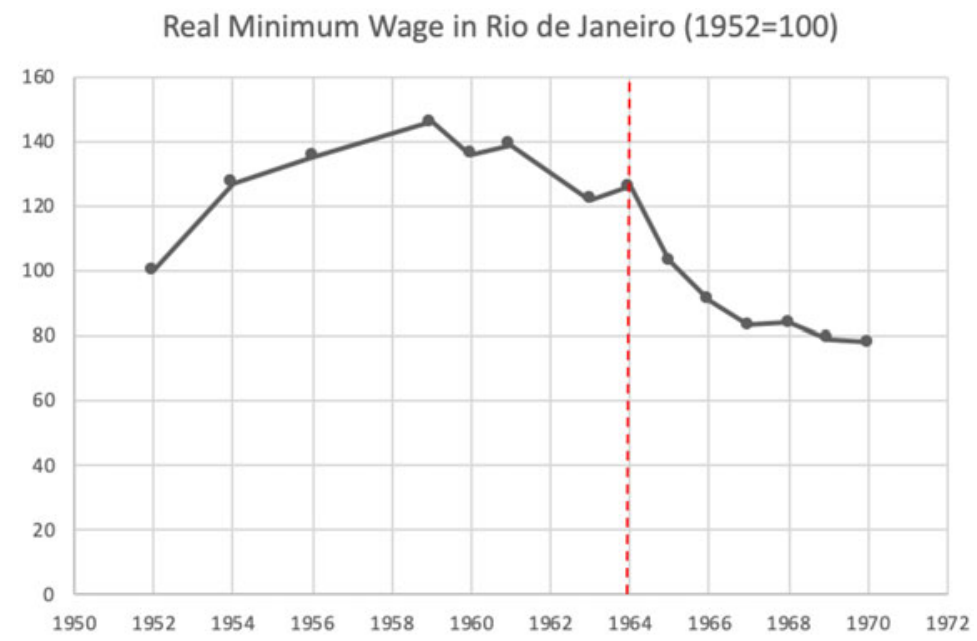

Figure I. Real minimum wage in Rio de Janeiro, 1952-70

Source: Lara Resende (I982) p. 779, based on IBGE Anuário Estatístico do Brasil.

unequal treatment that these two fairly similar plans received from international creditors (Ribeiro 2006). Thanks to 'generous' external support, Castello Branco's economic plan avoided the 'external strangulation' experienced by the earlier plan (Bastian 20I3, p. I 59), thereby alleviating the pressure on the balance of payments, which remained in equilibrium in 1964 (US\$2 million deficit) and in surplus in I965 (US\$2 I 8 million) compared to a substantial deficit in I962 (US\$ I 8 million in I962) and I963 (US\$37 million) (Bastian 2013, p. I64).

On 5 December I964, thus, Bulhões requested a US\$I 5 million SBA, to be effective from I January i $965 .{ }^{33}$ Two days later, Del Canto sent Bulhões a list of actions that his government would be required to institute before the SBA's request could be submitted to the EB vote. These actions included, among others, determining the percentages of the surcharges on import payments and on financial payments; the abolition of export restrictions; the introduction of exchange retentions on exports; and tariff increases. Del Canto requested that Campos should update Schweitzer directly once such decisions were taken and send weekly updates to the WHD. ${ }^{34}$

It seems that these two uncommon requests reflected Del Canto's reservations about Brazil's capability to fully implement the economic plan that the SBA was aimed at supporting. A secret memorandum further reveals his doubts and concerns.

33 EBS/64/200, 'Brazil - Request for a Stand-By Arrangement', 5 December I964, ref. 26628 I, digital doc. 224477, IMFA.

34 Confidential memorandum, Del Canto to Bulhões, 'Stand-By Arrangement', 7 December I964, Brazil Country Files, Immediate Office Sous-fonds, WHDAI, box 34, folder I, file: Brazil (I964-5), IMFA. 
Del Canto was apprehensive that the lack of a central bank in Brazil would impede the plan's implementation. This worry evaporated on 3 I December I964, a few days before the EB vote on the SBA request, when, partially due to IMF pressure, Brazil founded its Central Bank. ${ }^{35}$

In any case, in December, the SBA proposal was submitted to the EB. The WHD recommendations stressed that the SBA was aimed at supporting Brazil's PAEG, which, among others, outlined agrarian and administrative reforms and the modernisation of the banking system. ${ }^{36}$ The basic objectives for I 965 were to decelerate inflation and to reactivate economic growth in order to obtain a GDP annual rate of increase of about 6 per cent in I965-6. Changes in the taxation system included making the personal tax more progressive, maintaining the corporation tax rate at 28 per cent, establishing a new petroleum tax and imposing limits to total budget expenditures. ${ }^{37}$ The WHD concluded that if applied in full, the PAEG would lead to a drastic reduction of the inflation rate by late 1965 . One should keep in mind that the plan was expected to generate price increases and, consequently, labour unrest. The IMF stressed that the government would have to be firm and resist pressure to augment wages in the public sector or allow credit expansion. Del Canto believed that Castello Branco's military regime could, and would, resist such pressures. $^{38}$ The EB approved the first SBA to Castello Branco's regime on I 3 January I965. ${ }^{39}$ This paved the way for additional credit. In December I964, the US Treasury signed a US\$I 50 million programme loan for Brazil from the US-AID. Ultimately, US loans to Brazil in I965 totalled over US $\$ 450$ million. ${ }^{40}$ In March I965, I6 US commercial banks granted Brazil credit worth US $\$ 80$ million, ${ }^{41}$ while European bankers agreed to lend Brazil US\$50 million. ${ }^{42}$

In February I965, a new IMF mission arrived in Brazil. It reported that Brazil was advancing positively with the SBA and had requested two technicians to advise the Central Bank's Exchange Department. The Brazilians stressed that they wanted technicians recommended by the Fund but not associated with it - a rather uncommon

35 Secret memorandum for files by Del Canto, 'Discussions with Roberto Campos', io December I964, Brazil Country Files, Immediate Office Sous-fonds, WHDAI, box 34, folder I, file: Brazil (I964-5), IMFA.

36 Confidential EBS/64/2 Io, 'Brazil - Request for Stand-By Arrangement', 3 I December I964. ref. 266I67, digital doc. 224478, IMFA.

37 EBS/64/2IO.

38 Ibid.

39 EBM/65/3, I3 January I965, ref. 266073, digital doc. I80378. IMFA.

40 Treasury Department press release, 'US and Brazil enter new exchange agreement', 23 February I965, Brazil Country Files, Immediate Office Sous-fonds, WHDAI, box 34, folder 2, file: Brazil (I964-5), IMFA.

41 Bulhões to Schweitzer, 29 March I965, attachment to EBS/65/5I, 'Brazil - Modification of Stand-By Arrangement', ref. 265523, digital doc. 224733. IMFA.

42 Finch to managing director, 'Visit to Frankfurt for banker's meeting on Brazil', 24 March I965, Brazil Country Files, Immediate Office Sous-fonds, WHDAI, box 34, folder 2, file: Brazil (I964-5), IMFA. 
request that Del Canto nonetheless accepted. ${ }^{43}$ It seems that the dictatorship and the IMF were equally interested in blurring the deep traces of the IMF's involvement in the turbulent domestic sphere.

Problems, however, were quick to arise. On 3 April, Del Canto reported that the Bank of Brazil was exceeding the ceilings stipulated in the SBA. ${ }^{44}$ On 28 April, in order to avoid declaring that Brazil had violated these ceiling limitations and thereby increasing the risk that the agreement would be stopped, a minor modification of the SBA was approved. ${ }^{45}$ This change, though minor, was significant. It clearly shows the IMF's tendency to downgrade the seriousness of economic problems so long as the regime in power was ready to follow its policy recommendations. Moreover, in June, Del Canto reported that the Brazilian government feared a recession. ${ }^{46}$ In order to certify Brazil's eligibility for the next drawing, Del Canto began to organise a mission scheduled to arrive in Brazil around I 2 July. However, the impression at the WHD was that Bicalho was hesitant to accept the IMF's presence in the country 'in view of the heated controversy around the Plan that [was] going on in Brazil'. ${ }^{47}$ Yet a large IMF mission headed by Del Canto visited Brazil from 2 November to I6 December and opened SBA negotiations. ${ }^{48}$ While in Rio, it was in touch with a WB mission and with Ambassador Gordon and a US team that was negotiating a new aid programme. ${ }^{49}$ Negotiations with the IMF, WB and US government continued to take place also after October 1965, when Castello Branco issued the AI-2.

On I6 December I965, Bulhões requested a second SBA for US $\$$ I 25 million. ${ }^{50}$ In its recommendations, and despite the problems already mentioned, the WHD stressed that Brazil's economy had made substantial progress over the course of $1965 .{ }^{51}$ On 2 February I966, the EB approved Brazil's request. While detailing the measures adopted by the Brazilian government, Del Canto mentioned incentives in the

43 Office memorandum, Del Canto to deputy managing director, 'Brazil', I6 February I965, Brazil Country Files, Immediate Office Sous-fonds, WHDAI, box 34, folder 2, file: Brazil (I964-5), IMFA.

44 Del Canto to managing director, 'Luncheon with Minister Campos', 3 April I965, Brazil Country Files, Immediate Office Sous-fonds, WHDAI, box 34, folder 2, file: Brazil (I964-5), IMFA.

45 Confidential EBS/65/70, 'Brazil - Modification of Stand-By Arrangement', 28 April I965, ref. 265289, digital doc. 224734, IMFA.

46 Office memorandum, Del Canto to acting managing director, 'Brazil', June 3, I965, Brazil Country Files, Immediate Office Sous-fonds, WHDAI, box 34, folder 2, file: Brazil (I964-5), IMFA.

47 Confidential letter to Sacchetti, I I June I965, Brazil Country Files, Immediate Office Sous-fonds, WHDAI, box 34, folder 2, file: Brazil (I964-5), IMFA.

48 Sullivan to Gosselin, 'Additional per diem for Brazilian mission', I9 November I965, Brazil Country Files, Immediate Office Sous-fonds, WHDAI, box 34, folder 3, file: Brazil (I964-5), IMFA.

49 Confidential office memorandum, Del Canto to managing director and deputy managing director, 'Brazil', I7 December I965, Brazil Country Files, Immediate Office Sous-fonds, WHDAI, box 34, folder 3, file: Brazil (I964-5), IMFA.

50 Confidential EBS/65/207, 'Brazil - Request for SBA', ref. 263709, digital doc. 224738. IMFA.

51 SM/66/II, 'Brazil - i965 Article XIV consultations', 2 I January I966, ref. 263473, digital doc. I67037. IMFA. 
building industries; a 30 per cent increase in railroad rates; a reduction in the interest rate on rural credit; a programme of new fiscal incentives; decontrolling of meat prices; adjustment of gasoline and petroleum prices to the new exchange rate; new limits to wage increases; and more. ${ }^{52}$ Weeks later, Brazil sent a formal request for technical assistance, which the IMF approved. ${ }^{53}$ In the meantime, US private investments in Brazil increased, reaching nearly US\$I billion. ${ }^{54}$

The implementation of the second SBA was not without its challenges. Two IMF missions, in mid I966, focused on the coffee policy and decreasing earnings; bank credit, which continued to expand at a rate of $2.5-3$ per cent per month; and the balance of payments. ${ }^{55}$ In October, Del Canto arrived in Rio to negotiate a third SBA. This time, the Brazilians wanted a US\$30 million SBA, as 'they were more interested in the arrangement for the internal discipline it would provide, rather than for the financial support it would offer'. This was by no means extraordinary. More than once, countries signed SBAs not because they intended to draw the money but because they needed the IMF's seal of approval. In fact, the implementation of the US-AID assistance programme in the country depended on Brazil's entering into a new SBA. ${ }^{56}$

On 22 December I966, Bulhões requested a US\$30 million SBA, which the EB approved on I 3 February I967. As in the previous EB meetings, no political questions about Brazil's dictatorial regime were asked. ${ }^{57}$ On 27 January 1967, Del Canto held a I 5-minute meeting with the man who would go on to become the next president of Brazil, Artur da Costa e Silva. The latter referred to the forthcoming annual meeting in Rio and said that he hoped to address the opening session to which Del Canto enthusiastically responded that the IMF 'would not consider the meeting fully successful unless he were to address [the participants]'. Costa e Silva then said that he was looking forward to a discussion at the Rio meeting about 'the important subject of the international monetary reform' to which Del Canto responded affirmatively. 58

52 EBM/66/6, 2 February I966, ref. 263363, digital doc. I76283. IMFA.

53 EBM/66/I3, 23 February I966, ref. 263 I99, digital doc. I80648. IMFA.

54 'US investments near I billion', Brazilian Bulletin, 22(467), March I966.

55 Finch to managing director and deputy managing director, 'Mission to Brazil, 23 May - 7 June I966', 9 June I966 and office memorandum, Guenther to managing director, 'Visit to Brazil, 4-6 July I966', I I July I966, Brazil Country Files, Immediate Office Sous-fonds, WHDAI, box 35, folder I, file: Brazil (I966-8), IMFA.

56 'Briefing for mission to Brazil', prepared by the WHD and the Exchange and Trade Relations Department, 3 November I966, Brazil Country Files, Immediate Office Sous-fonds, WHDAI, box 35 , folder I, file: Brazil (I966-8), IMFA.

57 EBM/67/IO, I3 February I967, ref. 26035I, digital doc. I80583. IMFA.

58 Office memorandum, Southard Jr to Del Canto, 'Conversations with the president-elect of Brazil', 27 January I967, Brazil Country Files, Immediate Office Sous-fonds, WHDAI, box 35, folder 2, file: Brazil (I966-8), IMFA. 


\section{IV}

The relationship between Brazil and the WB, as Burke J. Knapp (WB vice president) put it, was 'more unhappy and strained than [with] any other member' (Kapur et al. I997, p. I05).

Brazil received its first WB loan in I949. With a total of I I loans in the I950s, Brazil became one of the WB's main clients. Yet WB lending was interrupted after the suicide of President Getulio Vargas in I954 (until I958) and then again from I959 to I965 during the presidencies of Kubitschek, Quadros and Goulart. This is even more remarkable given that at the time Brazil was among the fastest growing economies in the western hemisphere.

The first WB loan to Brazil was granted 27 January I949, to Brazilian Traction, a foreign-owned utility company operating in southeast Brazil (US $\$ 75$ million), and was not warmly received by the government who would have preferred the loan to be in favour of a state-owned company or project. The second loan was for a US\$IS million project to develop the potential of the San Francisco River and provide hydroelectric power to the northeast.

The WB-Brazil relationship continued to strengthen throughout the early I950s. By I95 I, a joint Brazilian-US Commission for Economic Development was established. Projects approved by the commission were presented to the WB and the Eximbank for financing. The first US head of the commission (co-directed with a Brazilian) was Francis Adams Truslow, former head of the New York Curb Exchange who had previously served as head of the WB mission to Cuba. One of Truslow's first decisions was to agree to set up a Brazilian Development Bank to finance the local currency costs of the projects that the commission was expected to present to the WB and Eximbank. Unfortunately, Truslow died while en route to Rio in July I95I. The US sent Mervyn Bowen to act as US head of commission until Burke Knapp obtained leave of absence from the WB and was able to take Bowen's place. Bowen filled the position for one year.

The projects financed by the Bank in I952-3 were essentially those presented by Brazil after having been approved by the commission. By early I954, the Bank made Io loans totalling US\$I94 million principally for power production (seven loans totalling US\$I 66 million) and railways (two loans totalling US\$25 million). The relationship soured as coffee prices began to fall at the end of I954 and Brazil's financial position deteriorated. Between I954 and I959, the price of 'Santos 4 Coffee' on Wall Street decreased from 78.9 cents/pound to 36.9 cents/pound. ${ }^{59}$ After I954, the Bank ceased lending operations in Brazil until fiscal rectitude was assured. In the period I954-6 Brazil received several loans from the United States, including a commitment of US\$I50 million from Eximbank for the railways.

59 Speech by Ambassador Lincoln Gordon on terms of trade and the Brazilian balance of payments to the National Economic Council, 29 January I963, I842903, World Bank Group Archives (henceforth WBGA). 
Things improved further when technocrats such as Lucas Lopes and Roberto Campos became part of Kubitschek's economic team and led the efforts to elaborate the Plano de Metas and, subsequently, the Plano de Estabilização Monetária (PEM) (Lopes I99I). ${ }^{60}$ The Furnas Hydroelectric Project was financed in 1958 by the Bank with a US $\$ 73$ million loan for the first stage of what was at the time the largest hydroelectric project ever undertaken in Latin America. After Lucas Lopes suffered a stroke and the PEM was abandoned, the WB once again ceased its lending operations in Brazil. Apart from ideological discrepancies, the relationship was made especially difficult by Brazilian unwillingness to give much-needed rate adjustments in the energy sector, in which the Bank was deeply financially involved, thus forcing 'the private utilities into a hopeless financial position'. 61

In February I962, Campos, now as ambassador of Brazil in Washington, DC, headed a delegation composed of the president and two directors of the Centrais Electricas de Urubupungá (a company created by the State of São Paulo in I95I) to the WB. The delegation met with Knapp and Barend A. de Vries (at the time economic adviser to the WB-WHD) to discuss the Bank's interest in supporting the first stage of the construction of a hydroelectric project involving eight units of I66MW each for an estimated amount of US\$ 50 million. Knapp responded that although 'the Bank was in a position to do this type of financing', it 'could not discuss financing of the Urubupungá project at the present time, having regard to Brazil's unsatisfactory financial position, both internal and external'. Knapp concluded with a damning remark: 'Until confidence has been restored in Brazil, we have to delay consideration of any project. ${ }^{, 62}$

The meeting preceded, by two months, the meeting between newly elected Brazilian president Goulart and WB president Eugene Black (I949-63). In a memorandum, Orvis Schmidt (director, Department of Operations - Western Hemisphere) briefed Black on potential topics of discussion. With regards to the conditions to resume lending, Schmidt remarked that 'the Bank could not lend until it sees a prospect of Brazil's carrying out a program which would effectively strengthen its international position and give us grounds for a judgement that the total service on Brazil's external debt ... would be within Brazil's ability to pay on schedule'. ${ }^{63}$ With regard to International Development Association (IDA, part of the World Bank Group) lending, Schmidt suggested Black take a tough stance on that topic as well, saying that 'until Brazil takes measures to stabilise its domestic financial position (balance the budget) and stop the drain on its resources ... the use of IDA resources would not be justified'. Not unexpectedly, given these premises, Goulart's mission was a failure.

60 On the Plano de Metas and PEM see, for example, Lucas Lopes's memoir (I99I).

61 Schmidt to Woods, background on Brazil, I2 March I963, I842093, WBGA.

62 Brazil-Urubupungá Project, I2 February I962, I833043, WBGA.

63 Forthcoming meeting with President João Goulart of Brazil, 4 April I962, I833043, WBGA. 
In February I963, a memorandum on Brazil was submitted to the WB executive board. The picture of Brazil under Goulart was bleak and tainted by the fear, among US and WB officials, of an imminent Marxist takeover. According to the memorandum's author, David Beaty III, over the previous I 5 years 'the communist party has been making great headway in placing members of its apparatus in key government posts'. Furthermore, 'when Jango Goulart became president he brought with him a group of leftist advisors, thereby accelerating this infiltration into important key positions' ${ }^{64}$ On the economic front, inflation was rising by 50 per cent year-on-year. In October I962, the last gold reserves of around US\$60 million were sold to satisfy commercial debts. Beaty estimated that Brazil's exports would be US\$I5O to US\$200 million less than in I96I, partly because coffee exports (which accounted for 60 per cent of Brazil's export) were, through November I962, 620,000 bags less than in I96I, or down about 4 per cent. Distrust in the economic policies and institutional reforms of the Goulart government was also evident in Beaty's memorandum. A new law on profit remittances and a revised income tax law were especially criticised: 'due to the lack of confidence in the administration of these laws, the effect has been to accelerate the flight of capital out of Brazil and further discourage the foreign investor'. If in the past years foreign investments had provided around US $\$ 300$ million per year to Brazil's balance of trade, with the 'present lack of confidence almost all of this will be lost to the country'. ${ }^{65}$ Beaty concluded, 'what do we look forward to in Brazil?' He expected growing nationalism, 'continuation towards the socialistic state' and 'further infiltration on the part of the communists into key government posts and trade unions'.

In March 1963, finance minister San Tiago Dantas was scheduled to meet with George Woods, former chairman of First Boston Corporation who succeeded Black as president of the WB in I963. As indicated above, the goal of Dantas's visit was to illustrate the Plano Trienal to Woods in the hope of receiving US, IMF and WB support. The task was made more difficult by the government's inflationary policies and by the shaky external financial position resulting from an overvalued exchange rate, a poor cocoa harvest and an uncertain coffee policy.

Prior to this meeting, Schmidt prepared a memorandum to brief Woods. According to Schmidt, the biggest issues facing Brazil were: excessive investments in politically motivated projects; excessive fiscal deficits financed by the Central Bank $^{66}$ fuelling inflation; monetary inflation; external imbalance because of excessive imports; excessive indebtedness because of the reliance on short-term borrowing; last but not least, anaemic economic growth. With regards to the attitude of the Bank towards Brazilian requests for assistance, Schmidt suggested Woods take a hard

64 David Beaty III to the Board of Directors, 6 February I963, I842903, WBGA.

65 Ibid.

66 Sic in the original text. Given that the creation of a proper central bank would not occur until I964, Schmidt was probably referring here to the Banco do Brasil. 
stance. According to Schmidt, 'until Brazil takes measures to strengthen its financial positions and use its resources more efficiently, neither the IDA nor the Bank can help'. ${ }^{67}$ The IMF shared the same view and de Vries reported: 'Although the meeting had been held in a friendly atmosphere, the Fund officials had made it clear that the Fund could not enter into a new standby agreement on the basis of the steps the Brazilians had taken thus far, but that more performance was needed. ${ }^{68}$

On the Bank's side, even before sending a mission to assess the economic position or study potential projects, 'the Bank would want to know that Brazil has a program capable of achieving the desired objectives and have the Government take some steps toward carrying it out'. Under these circumstances, the meeting which took place on I 3 March was not really conclusive. Dantas illustrated Brazil's economic plans, asked for an economic mission to visit Brazil 'right away' and invited Woods and his wife to visit the country. Woods replied that he couldn't commit to when such a mission would take place, saying: 'it might be next summer or it might be in the fall'. With regards to the personal invitation, Woods said that 'he would certainly like to do so soon but could not say just when it would be possible'. As Figure 2 shows, the macroeconomic and political situation in Brazil was spiralling out of control, or, at least, this was the perception of foreign investors.

The Brazilians sent a new mission headed by Carlos Alberto Alves de Carvalho Pinto, the new minister of finance who replaced Dantas, to have a meeting with WB officials in Washington in October I963. After the usual courtesies, Carvalho Pinto opened by saying that the government of President Goulart had been working hard to rectify its 'critical financial situation'. ${ }^{69}$ Coping with a severe recession accompanied by rising fiscal deficits and inflation (Ayres et al. 2018), cash and support were badly needed. Weakened financially and increasingly challenged on the political front, the meeting between Carvalho Pinto and the WB took place during one of the most difficult periods of Goulart's presidency. Since September I963, the failure of the anti-inflationary measures and the final defeat of Goulart's ambitious agrarian reform weakened the president on both sides of the political spectrum. In Santos, a general strike was coordinated by the powerful Comando Geral dos Trabalhadores (CGT). The same month, lower-rank officers occupied several locations in Brasilia, including the Ministry of the Navy and the National Congress, establishing the Comando Revolucionario de Brasilia. The revolt only lasted I2 hours, following which over 500 members of the military were imprisoned. Carvalho Pinto was adamant in pointing out that it would take time to put together a plan that would satisfy the IMF but he hoped that the Bank would be ready when this finally happened 'since Brazil would subsequently have to depend very much on the Bank'.

67 Background on Brazil, I2 March I963, I842903, WBGA.

68 Barend A. de Vries, 'Brazil - Results of recent negotiations with finance minister San Tiago Dantas', 28 March I963, I842903, WBGA.

69 'Brazil - Minutes of the meeting between Mr. George D. Woods and C. A. Carvalho Pinto, Brazilian minister of finance', 9 October I963, I843043, WBGA. 


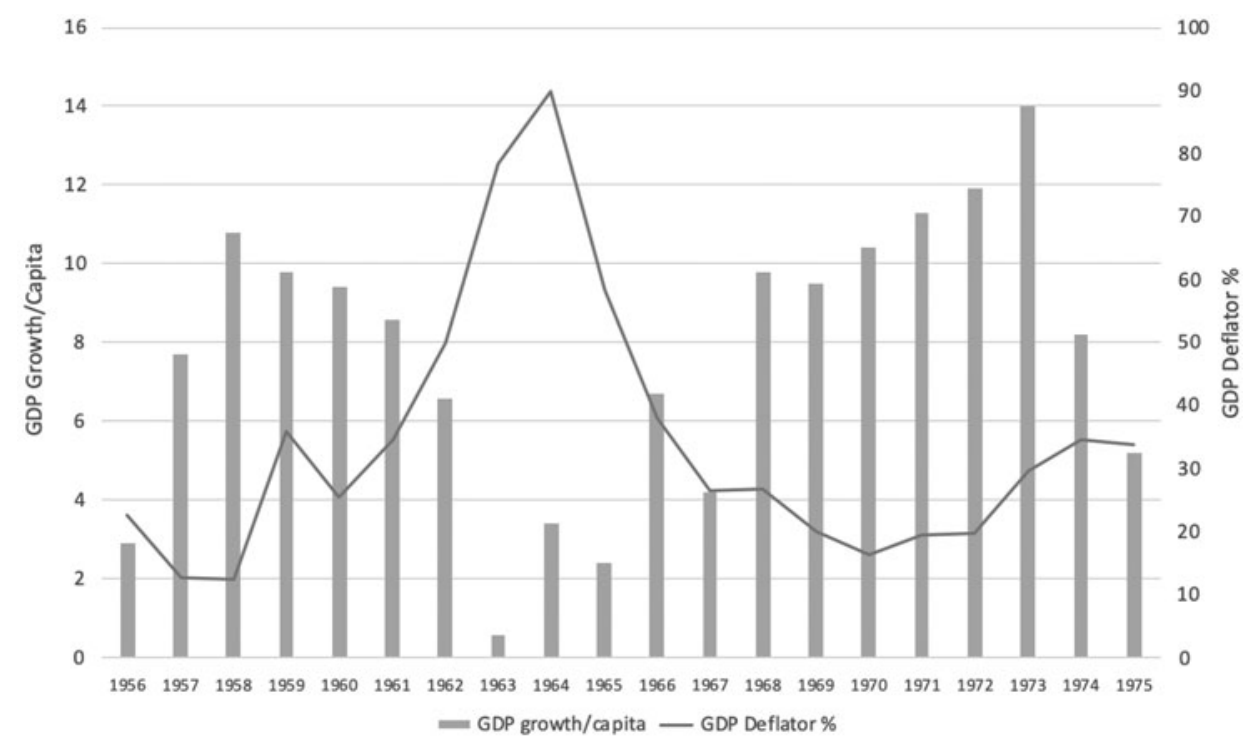

Figure 2. GDP/capita growth and GDP deflator in Brazil, 1956-75

Source: IBGE Estatísticas Históricas do Brasil, Rio de Janeiro, I990.

Given Brazil's financial needs, particularly worrisome was the structure of the country's debt. Cut off from most sources of long-term financing, Brazil had to resort to short-term loans that were aggravating its already precarious balance sheets. After this initial statement, Carvalho Pinto went straight to the point and inquired whether the Bank was prepared to resume lending to Brazil'.

Woods was not impressed by Carvalho Pinto's request. He told his interlocutor that 'the Bank would very much like to resume lending to Brazil but it would have to be at the proper time and under the proper conditions'. Crucially, before making any decision in favour of Brazil there would have to be a 'meeting of minds with the IMF'. Also, Knapp stressed, Brazil would first need to 'rectify the position of her budget, balance of payments and external debt'. The meeting ended in failure, with Brazil continuing not to receive any help for the time being from the Bank.

Mirroring the attitude of the IMF, the troubled relationship with the Bank did not mean that the contacts between the Bank and the Brazilian government were interrupted completely. In November I963, a few weeks after Carvalho Pinto's mission, de Vries flew to Brazil to attend the Inter-American Economic and Social Council. During and after the conference, he spent time in Brazil in a private capacity. After talking to São Paulo industrialists, de Vries reported to the Bank that they were 'very discontented with the lack of leadership displayed by Goulart, but, on the other hand, also seemed quite confident of the future' ${ }^{70}$ The 'root of the problem'

70 Notes on visit to Brazil (3 I October - 21 November I963), 4 December I963, I842903, WBGA. 
in Brazil, according to de Vries, was the deficit in the public sector which was expected to reach around US $\$ 400$ million by 1963 ; de Vries reported that he left Brazil 'with the feeling that in no single sector was the Government trying to achieve any retrenchment'. The cause of these huge deficits was, de Vries reported, twofold. On the one hand, the Brazilian government was investing at an unsustainable rhythm, on the other, President Goulart was too weak when dealing with labour demands. The latter aspect had resulted in a government wage bill taking up an increasing share of total expenditures, and a substantial operating deficit for the railroads and the merchant marine. According to de Vries, 'Even if Goulart were to be replaced by a much stronger Government, it would have a hard time managing the persistent demands for higher wages which broad sectors of the population have come to expect with large-scale industrialisation and urbanisation, and the improvement in communications.'

The very last meeting between the democratic government of Brazil and the Bank took place in Geneva on 25 March when Woods met Vilar de Queiroz, who was in charge of the renegotiation of Brazilian debt. After making it clear to Woods that 'there is NO [sic] suggestion that any debt owing by Brazil to the World Bank should be rescheduled', Woods told de Queiroz to visit him at the Bank the following week when a Brazilian delegation was scheduled to be in Washington, DC, for consultations. This meeting was fated never to take place, as the military coup of I964 overthrew the democratically constituted government of Brazil and inaugurated one of the longest periods of military rule in Latin America in the past century.

As Figure 3 illustrates, once Goulart was out of the way, the relationship between Brazil and the WB changed dramatically, so that it is possible to talk of a before and after scenario economically as well as politically.

A mere month after the coup, Knapp met with two officials from the US State Department prior to their departure on a six-day mission to Brazil, in order to update them about the Bank's 'current thinking' on Brazil. ${ }^{71}$ After outlining the problems between the Bank and the Goulart administration over the previous few years, Knapp told his guests that 'the Bank may soon want to take a fresh look at the situation in Brazil and determine whether it can resume lending on a larger scale'. The first act of the new relationship between the Bank and the regime was the invitation extended to Woods by Bulhões, to send a mission to Brazil as soon as possible. Bulhões wrote to Woods that 'it is my conviction that the financial measures now being undertaken by this Government will go to a long way towards creating an appropriate climate'. 72 The invitation was forwarded to Woods by Israel Klabin, an industrialist and heir

71 'Brazil and Colombia - Meeting with US representatives', 5 May I964, I843043, WBGA.

72 Ibid. 


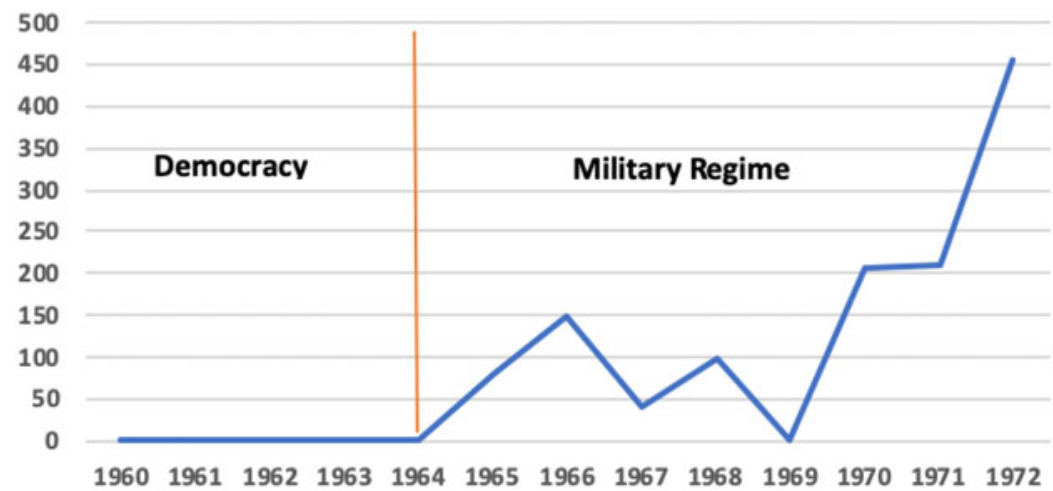

Figure 3. World Bank lending to Brazil, 1960-72 (in million US\$)

Source: World Bank projects and operations https://projects.worldbank.org

to Klabin Irmãos \& Cia. Klabin ${ }^{73}$ had been invited to the United States by a group of American bankers and industrialists, led by David Rockefeller as chairman of the Business Group for Latin America, who were interested in developing business relations between the Brazilian and American communities. The group of Brazilian businessmen included several representatives from the Institute for Economic and Social Research (IPES) including one of its founders, Paulo Ayres Filho, who in I987 said that 'the I964 Revolution was made in my living room' (Schneide 2019, p. I 59).

During his North American tour, Klabin also visited Knapp. The latter's attitude during this visit was markedly different from previous encounters with Brazilian delegates. Knapp 'assured Mr. Klabin that the Bank is very eager to work closely with the new Brazilian government'. ${ }^{74}$ Woods, not entirely surprisingly, responded positively to Bulhões's request and replied that he had instructed Schmidt, de Vries and two other officials to visit Brazil in the third week of June. The 'Schmidt mission' that arrived on 23 June in Rio, less than three months after the coup, inaugurated a long and fruitful relationship between the WB and Brazil's military regime. The goal of the mission was to prepare the ground for a larger mission later that year.

Once back in Washington, Schmidt reported on his trip to the country. He remarked that the 'first matter to record is the important change in the general climate in Brazil'. ${ }^{75}$ Schmidt was especially appreciative of the ministerial team composed of 'men of integrity and competence', starting with Bulhões (minister of finance), Mauro Thibau (minister of mines and energy), Juarez Távora (minister of transportation), Campos (minister of planning) and Vasco Leitão da Cunha (minister of foreign affairs). During discussions held with Benedicto Dutra (deputy minister of mines and energy), the Bank decided to support several projects for an initial amount

73 At the time, it was Brazil's major pulp and paper manufacturer.

74 'Brazil - Meeting with Israel Klabin', 27 May I964, I843043, WBGA.

75 'Highlights of visit to Brazil (23 June - 2 July I964)', Io July I964, I 843043, WBGA. 
of US $\$ 75$ million (around US $\$ 600$ million today). The relationship with a large and prestigious institution such as the WB was not only essential to secure funding for development projects but also, and probably more importantly, for political reasons. The political role that the Bank played was evident to Brazilian policymakers. During a high-level meeting in Tokyo in September I964, which included Woods, Knapp and Bulhões among others, Bulhões began the meeting by inviting Woods to Brazil, adding that 'such a visit was important for political reasons'. ${ }^{76}$ Woods replied cordially that he was 'personally very sympathetic to the idea of visiting Brazil'.

The relationship between the Bank and the Brazilian regime, despite ups and downs, continued to strengthen in the second half of the I96os. After the first loans that followed Schmidt's mission money continued to flow into Brazil. In April I965, the WB Loan Committee authorised a one-year lending programme of US\$I 30 million for three power projects, which was subsequently raised to US \$ I 50 million.

The Bank remarked in September I965 that 'Since the revolution, the Government has given ample evidence of capacity to take decisive action on difficult and unpopular issues of policy and institutional reform. ${ }^{77}$ By June I966, the issue on the table was whether to increase by a further US $\$ 200$ million the loans to be made during the fiscal year I966-7. The Bank appreciated that the increase in prices had been slowed, that the government's budget deficit had been cut, that export controls and price subsidies had been eliminated, and that the government was pursuing a flexible exchange rate policy. On the negative side, inflation proved to be more stubborn than anticipated. ${ }^{78}$ Ultimately, the confidence in the regime's policies justified an increase of US $\$ 200$ million in Bank loans for the period I966-7. The flow of money reflected the increased frequency of interactions between the Bank and Brazil, notably a substantial increase in the number of WB economic missions. After neglecting Brazil for more than five years during democratic rule, the Bank now started to pay regular visits to the military regime, sometimes several times per year. By August I966, a new visit was planned for November-December I966, the third such mission in less than three years. The Bank was aware of its close links with the regime and recognised that the upcoming I966 mission was "part of a process initiated in I964 to resume Bank lending operations in Brazil on a significant scale, after several years during which the contacts between Brazil and the Bank were minimal'. ${ }^{79}$ The fact that the Bank was openly speaking of a 'process initiated in I964' seems to suggest that there was a plan to allow the new military regime to access Bank resources prior to the implementation of satisfactory monetary and economic policies,

76 Meeting with Brazilian delegation, Okura Hotel, Tokyo, 9 September I964, I843043, WBGA.

77 Briefing paper - Brazil i965, I6 September I965, I843043, WBGA.

78 Economic policy memorandum from the Western Hemisphere Department, Io June I966, I843006, WBGA.

79 'Economic mission to Brazil - Terms of reference and staffing requirements', 22 August I966, I 843006 , WBGA. 
thus suggesting a possible bias in favour of the new regime. The context in which relations were renewed was that of a 'new government making unprecedented efforts to bring a long and intractable inflation under control'. The Bank, though, quickly realised that even a repressive regime committed to monetary orthodoxy could have trouble eradicating inflation. In their back-to-office report, Bank's officials who visited Brazil (the mission was postponed until January I967) reported that 'The main disappointments are in the areas of price stabilization and economic growth. ${ }^{80}$ In I966, inflation remained at around 60 per cent, roughly half its I963 levels but in line with the preceding years.

The end of Castello Branco's mandate coincided with the end of the Campos and Bulhões reign over the Brazilian economy. The new administration of Costa e Silva, who visited Washington to meet Woods in January I967, heralded the arrival into power of Helio Beltrão at the Ministry of Planning and of the young economist Antônio Delfim Netto at the Ministry of Economy. In his first visit as president-elect, Costa e Silva remarked that the policies of the new administration would continue to be in line with those implemented since the coup namely, 'austerity, dignity, constraint on Government outlays and maintaining adequate momentum in the process of economic development. Brazil would also continue to keep hers doors open to the inflow of private foreign investment. ${ }^{81}$

The next six years would be known as the 'Brazilian economic miracle' and would be marked by a reorientation of the monetary policy under Delfim Netto in favour of an increased focus on reactivating economic growth made official in the new Plano Estratégico de Desenvolvimento (PED) (Macarini 2000 and 2006). Despite occasional tensions between the Bank and the regime's new technocratic elite, especially in the first two years of the Costa e Silva administration marked by the return of economic heterodoxy, Gerald Alter (director of WHD) would propose an ambitious five-year lending programme to Brazil of US\$I billion, starting from US $\$ 75$ million in I968-9 and rising to about US $\$ 300$ million by I972-3. The five-year plan was approved by the Bank's Economic Committee in August I968. By the late I96os, Brazil had finally become a creditworthy borrower and, consequently, one of the largest recipients of Bank funding. In summary, recently disclosed primary sources allow us to reveal that World Bank officials, despite the insistence on objective economic criteria, also showed a more flexible attitude and generous disposition towards the generals. Contrary to current narratives on the political preference of international financial organisations (e.g. Payer I974), we do not find any concrete evidence that the WB was actively supporting a regime change through 'destabilizing non-lending' and, although we also do not find any evidence that the the goal of the WB was to integrate Brazil into the "worldwide economic system that the US constructed just

80 'Brazil mission - Back to office report', I3 March I967, I843007, WBGA.

81 Meeting between President-elect Costa e Silva of Brazil and Mr Woods, 30 January I967, I843045, WBGA. 
after World War II' (Swedberg I986, p. 384), we can see in the WB position a case of 'indirect political pressure' intended as economic conditions which carry important consequences for the politics of the debtor country (Swedberg I986, p. 384). For Brazil, a society deeply fragmented along socio-economic lines, complying with the requests of the WB involved taking harsh redistributive decisions that could only be carried out by a regime with a firm grip on the social and political sphere. In this case, the authoritarian character of the regime put the military in a much better position to deliver what the WB was demanding.

After being one of the largest clients of the WB in the late I940s and early I950s, the WB entered an increasingly confrontational relationship with the left-wing administrations that governed Brazil in the second half of the I950s until the coup of I964. Soon after the military takeover, bilateral relations were normalised and, once again, Brazil became one of the largest recipients of WB lending. During the same period, Brazil's relations with the IMF followed a somewhat similar path: relations were tenser when leftist administrations were in power but improved under right-wing dictatorships. Recently disclosed documents from the IMF and the WB archives shed new light on several issues that have hitherto been overlooked by scholars. First, the article has shown that although both institutions shared the same economic principles and a similar 'special relationship' with the United States, this did not necessarily imply that they always adopted the same attitude towards different Brazilian governments. In effect, while the WB did not approve any new loan to Brazil's leftist administrations between I959 and I964, the IMF proved to be a more flexible partner, granting a highly conditional SBA to Quadros's administration in I96I and a non-conditional CFF to Goulart's government in I963. Moreover, the IMF interrupted lending only when Brazil stopped complying with the terms of the SBA.

The fact that the lending patterns of the Fund and Bank towards Brazil before the coup were partially different cannot conceal a basic truth - that neither of them approved Goulart's economic policy and his strong ties with the labour movement, and that both went out of their way to establish fruitful cooperation with the new military regime, even before any concrete macro-economic improvement was achieved. This differential attitude was noticed by contemporaries. In July I964, The Economist published a provocative article entitled 'Creditors Prefer Generals' about the successful rescheduling of Brazil's medium-term debt, suggesting:

The new western warmth towards Brazil seems to have been kindled by the unceremonious departure in April of President Goulart, whose dilatory attitude towards his country's roaring inflation cost his government the sympathy of his creditors. These creditors consider the new regime of President Castello Branco with a kindlier eye, and show no great concern over its incursions into private and political liberties. For Brazil's new government has at least shown 
convincing signs of trying to restore economic order with credit curbs, cuts in state spending and increased taxation - all the politically unpopular measures before which Senhor Goulart had recurrent bouts of cold feet ... (The Economist, i I July i964)

What does this undeniable preference mean in terms of the self-imposed 'political neutrality' of the IMF and the WB? Did these institutions really prefer generals, and, if this was the case - why?

It is significant that the Plano Trienal launched in I962 by Goulart and the PAEG launched by Castello Branco in I964 were similar, both a hybrid mix of orthodox and heterodox economic measures that shared numerous parallels with regards to characteristics and policies. Given that despite the similarity of the economic plans, the two regimes were accorded vastly different treatment at the hands of the IMF and the WB, it seems relevant to suggest that the reasons for this treatment must have been, at least partially, politically motivated.

In fact, as new historical evidence reveals, the IMF and the WB doubted Goulart's political capacity to cut wages, eliminate subsidies and, ultimately, curb inflation. In contrast, the two institutions were confident that a strong, repressive military regime would have the ability to implement a stabilisation plan, even one that would result in a negative impact on the real salaries and purchase power of the workers and lower classes of society. Yet to conclude that the IMF and WB completely violated their self-imposed political neutrality would be somewhat simplistic. While it is true that the Plano Trienal and the PAEG presented several similarities and therefore deserved, at least in principle, the same response, it cannot be denied that the regimes of Goulart and Castello Branco did, in reality, support significantly different economic and social policies, had different scope for political manoeuvering and enjoyed very different levels of political power. The IMF, the WB and international investors in general were certainly well aware of these substantial differences and therefore hesitated or even refused to support Goulart but were keen to support the military regime.

Given that one cannot deny that the IMF and the WB were inclined to work with the Castello Branco military regime even when his economic plan was not fully implemented and/or when it showed alarming signs of an imminent crisis, but, by contrast, significantly downgraded their financial support to populist and left-wing regimes, the question is to what extent did this specific case constitute an anomaly or was it rather part of a broader strategy on the part of the Bretton Woods institutions? Did the IMF and the WB, in fact, prefer working with military rather than democratic regimes and/or with right-wing over populist/reformist administrations? While looking at the (still understudied) experience of other Latin American cases, the picture becomes increasingly complex and significant research must be carried out on a larger number of examples before clear conclusions can be reached. That being said, there are two studies, on Argentina and Chile, that have examined the issue and seem to indicate numerous parallels with the situation in Brazil. In Argentina, the populist administration of President Perón (I946-55) was not even accepted as a member state of the Fund and Bank, with its entry into both institutions not approved until I956, 
when the military regime that deposed Perón was in power. This regime, however, which governed the country until April I958, received neither a WB loan nor an SBA, and was only able, through special permission, to access a small amount of IMF funds. In Chile in the I970s, the WB management and staff held countless meetings with Allende's economic team but ultimately refused to submit his loan requests to the EB vote (mainly because the US representative threatened to veto any loans to the country). During the same period the IMF did grant Chile three CFFs, and in doing so emerged as the only institution in the Western Bloc to violate the economic embargo that the Nixon administration imposed against this socialist regime. Thus, while both institutions had a certain preference towards the military regimes, it is remarkable that in almost all cases indicated above, and despite the tough image of the IMF in its borrowers' eyes, it was more flexible and pragmatic than the WB. It would therefore not be illogical to suggest that it was precisely its tough, or even negative, image among leftist, populist and nationalistic political actors in Latin America, that, more than once, led the IMF to adopt a pragmatic and non-confrontational stand that allowed it to remain 'neutral' and enabled it to grant these regimes financial support. After all, the IMF's experience in Latin America had certainly taught it that political instability was by no means uncommon and that a new and more (neo)liberal regime would soon come to power. The IMF, which was harshly criticised in the region in the late I950s and I960s, by leftists as well as by structuralist economists, made efforts to improve its image in the region, out of fear that countries would stop borrowing from it, and seems to have used its 'neutrality' as the means of doing so. The WB, by contrast, was in a much better position than the Fund, as it knew that all regimes would have no choice but to come knocking on its door to request much needed development loans. Therefore, it could allow itself to be less pragmatic, or, in other words, less 'neutral'.

The case of the Frondizi government in Argentina is partially different from the other cases mentioned above. It was a democratic regime that, despite its nationalistic electoral rhetoric, promoted a significant liberalisation of Argentina's economy, including major efforts to attract foreign capital, limit the intervention of the state in the economic activity and promote the private sector. Following extensive negotiations and only after launching a stabilisation plan that was designed together with the IMF, was Frondizi able, in December I958, to receive Argentina's first SBA, followed by an additional SBA every year. Interestingly, the IMF continued to grant Argentina a new SBA every year up until I963, regardless of whether the regime was democratic or dictatorial. Here too the WB proved more intransigent than the Fund. It provided its first loans to Argentina in I96I and I962, and then stopped lending, which it didn't resume until July 1967, when the military were once again in power. When Peronism returned to power (I973-6) lending ceased again, only to be resumed after the military coup of 1976.

To conclude, while, at first glance, evidence from Brazil, as well as from Argentina and Chile, suggests that the IMF and the WB were more disposed to assist military rather than democratic regimes, it seems that the main reason was not an a priori 
preference for military regimes, but, instead, the natural - and by no means neutral inclination to work with regimes, military or democratic, that were more ready and able to follow IMF and WB recommendations. Undoubtedly, more research must be carried out in order to be able to more explicitly identify the IMF's and WB's patterns of action. What is clear is that the self-imposed 'political neutrality' of the Fund and Bank enabled both institutions to lend (or not to lend) to different regimes at different times, without risk of losing any member state while doing so.

Submitted: 26 November 2020

Revised version submitted: 23 March $202 \mathrm{I}$

Accepted: 3 May 202 I

First published online: 2I June $202 \mathrm{I}$

\section{Sources}

Brazilian Bulletin

Federal Reserve Bank of Minneapolis Staff Report

International Monetary Fund Archives

World Bank Group Archives

\section{References}

ALMEIDA, M. A. (20IO). A política econômica do governo João Goulart: restrições estruturais e vetos políticos. MA thesis, Universidade Estatual de Campinas.

ALTAMURA, C. E. (2020). Global banks and Latin American dictators, I974-I982. Business History Review. DOI:Io.IoI7/Sooo76805I900I 260

ALTAMURA, C. E. and FLORES ZENDEJAS, J. (2020). Politics, international banking and the debt crisis of I982. Business History Review, 94(4), pp. 753-78.

AMICCI, D. (20I2). La trayectoria hacia la Cumbre de Uruguayana: máxima expresión de la aproximación entre Argentina y Brasil durante el desarrollismo. CONfines, 8, pp. I33-56.

ANDERSEN T., HANSEN H. and MARKUSSEN, T. (2006). US politics and World Bank IDA-lending. Journal of Development Studies, 42(5), pp. 772-94.

AYRES, J., GARCIA, M., GUILLEN, D. and KEHOE, P. (2018). The monetary and fiscal history of Brazil, I960-20I6. Federal Reserve Bank of Minneapolis Staff Report 575, December.

BABB, S. (2009). Behind the Development Banks. Washington Politics, World Poverty, and the Wealth of Nations. Chicago and London: University of Chicago Press.

BARRO, R. and LEE, J. (2002). IMF programmes: who is chosen and what are the effects? NBER Working Paper 895I.

BASTIAN, E. F. (20I3). O PAEG e o Plano Trienal: uma análise comparativa de suas políticas de estabilização de curto prazo. Estudos Econômicos, 43(I), pp. I39-66.

BETHELL, L. and CASTRO, C. (2008). Politics in Brazil under military rule, I964-I985. In L. Bethell (ed.), The Cambridge History of Latin America, vol. IX: Brazil since 1930. Cambridge and New York: Cambridge University Press.

BOUGHTON, J. (20I2). Tearing Down Walls: The International Monetary Fund 1990-1999. Washington, DC: IMF.

BURNSIDE, C. and DOLLAR, D. (2000). Aid policies and growth. American Economic Review, 90(4), pp. $847-68$.

FISHLOW, A. (I974) Algumas reflexões sobre a política econômica brasileira após I964. Estudos CEBRAP 7, Jan./Mar., São Paulo.

FLECK, R. and KILBY, C. (2006). World Bank independence: a model and statistical analysis of US influence. Review of Development Economics, Io(2) pp. 224-40. 
FONSECA, P. C. (2004). Legitimidade e credibilidade: impasses de politica econômica do Governo Goulart. Estudos Econômicos, 34(3), pp. 587-622.

FREY, B. and SCHNEIDER, F. (I986). Competing models of international lending activity. Journal of Development Economics, 20(2), pp. 225-45.

FRIEDEN, J. (1987). The Brazilian borrowing experience: from miracle to debacle and back. Latin American Research Review, 22(2), pp. 95-I3 I.

GARCIA-HERAS, R. (20 I8a). Multilateral loans, banking finance, and the Martinez de Hoz Plan in Argentina, I976-I98 I. Revista de Historia Económica, 36(2), pp. 2 I 5-40.

GARCIA-HERAS, R. (20I8b). The return of international finance and the Martínez de Hoz Plan in Argentina, I976-I978. Latin American Research Review, 53(4), pp. 799-8 I4.

GUERCHON, C.W. (I97I). Institutional acts of the Brazilian government. International Journal of Politics, I(2/3), pp. 258-69.

GUITIÁN, M. (I992). The unique nature of the responsibilities of the International Monetary Fund. Pamphlet Series no. 46. IMF. www.imf.org/external/pubs/ft/pam/pam46/pam46.pdf

GWIN, C. (I997). US relations with the World Bank, I945-I992. In D. Kapur, J. Lewis and R. Webb (eds.), The World Bank: Its First Half Century, vol. 2. Washington, DC: Brookings Institution Press.

HEINZEL, M., RICHTER, J., BUSCH, P., FEIL, H., HEROLD, J. and LIESE, A. (2020). Birds of a feather? The determinants of impartiality perceptions of the IMF and the World Bank. Review of International Political Economy. DOI: IO. I080/09692290.2020. I7497 I I

HELLEINER, E. (2O I4) Forgotten Foundations of Bretton Woods: International Development and the Making of the Postwar Era. Ithaca, NY: Cornell University Press.

KAPUR, D., LEWIS J. P. and WEBB R. (I997). The World Bank: Its First Half Century, vol. I. Washington, DC: Brookings Institution Press.

KEDAR, C. (20I3). The International Monetary Fund and Latin America: The Argentine Puzzle in Context. Philadelphia, PA: Temple University Press.

KEDAR, C. (20I5). Salvador Allende and the IMF, I970-I973: the depoliticization and technocratization of Cold War Relations. Journal of Latin American Studies, 47(4), pp. 717-47.

KEDAR, C. (20 I 7). The International Monetary Fund and the Chilean Chicago Boys, I973-I977: cold ties between warm ideological partners. Journal of Contemporary History, 54(I), pp. I79-20 I.

KEDAR, C. (20 I 8). Economic neutrality during the Cold War: the World Bank, the United States, and Pinochet's Chile, I973-I977. Cold War History, I8(2), pp. I49-67.

KEDAR, C. (20I9a). Human rights and multilateral lending: the World Bank, Argentina and the United States, I976-I978. The International History Review, 4I(6), pp. I256-75.

KEDAR, C. (20I9b). The World bank lending and non-lending to Latin America: the case of Argentina, I97I-1976. Revista de Historia Económica, 37(I), pp. I I I-38.

KOFAS J. (2002). The Sword of Damocles: US Financial Hegemony in Colombia and Chile, 1950-1970. Westport, CT: Praeger.

LARA RESENDE, A. (I982). A politica brasileira de estabilização: I963/i968. Pesquisa e Planejamento Econômico, I2(3), pp. 757-806.

LOPES, L. (I99I). Memorias do Desenvolvimento. Rio de Janeiro: Centro da Memoria da Eletricidade no Brasil.

LOUREIRO, F. P. (20Io). Uma difícil conciliação: empresários e trabalhadores no contexto do plano trienal. Historia Económica e de Empresas, I3(2), pp. I09-43.

LOUREIRO, F. P. (20I3). O plano Trienal no contexto das relações entre Brasil e estados unidos (I962-I963). Revista de Economia Política, 33(4), pp. 67I-9I.

LOUREIRO, F. P. (2013). Dois pesos, duas medidas: os acordos financeiros de maio de I96 I entre Brasil e Estados Unidos durante os governos Jânio Quadros e João Goulart (I96I-I962). Economia e Sociedade, 22(2). https://doi.org/IO.I 590/So I04-06 I 820 I3000200009

LOUREIRO, F. P. (2OI4). The alliance for or against progress? US-Brazilian financial relations in the early I960s. Journal of Latin American Studies, 46(2), pp. 323-5I.

LOUREIRO, F. P. (20I7). Empresários, trabalhadores e grupos de interesse: a política econômica nos Governos Jânio Quadros e Joao Goulart, 1961-1964. São Paolo: Editora UNESP.

MACARINI, J. P. (2000). A política econômica da ditadura militar no limiar do 'milagre' brasileiro: I967/69. UNICAMP, Working Paper 99. 
MACARINI, J. P. (2006). A politica econômica do Governo Costa e Silva 1967-I969. Revista de Economia Contemporanea, Io(3), pp. 453-89.

PAYER, C. (1974). The Debt Trap: The IMF and the Third World. Harmondsworth: Penguin Books.

PEET, R. (2003). Unholy Trinity: The IMF, the World Bank and the WTO. London: Zed Books.

RABE, S. (1999). The Most Dangerous Area in the World: John F. Kennedy Confronts Communist Revolution in Latin America. Chapel Hill, NC: University of North Carolina Press.

RAMÍREZ, H. (20I2). El golpe de estado en Brazil desde una perspectiva socio-política. Historia Política, 5(9), pp. 255-66.

RIBEIRO, R. A. (2006). A aliança para o progresso e as relaçoes Brasil-Estados Unidos. PhD dissertation, Universidade Estatual de Campinas.

SCHNEIDE, N. (ed.) (2019). The Brazilian Truth Commission. New York and Oxford: Berghahn Books.

SEWELL, B. (20 I6). The US and Latin America. Eisenhower, Kennedy and Economic Diplomacy in the Cold War. London: Bloomsbury Academic.

SIMOES, G. (20 Io). Turbulencia política interna e política externa durante o Governo Castello Branco (I964-I967). MA thesis, Universidad de Brasília.

SKIDMORE, T. (1978). The years between the harvests: the economics of the Castello Branco presidency, I964-I967. Luso-Brazilian Review, I5(2), pp.I 53-77.

SKIDMORE, T. (1988). The Politics of Military Rule in Brazil, 1964-1985. Oxford and New York: Oxford University Press.

STAPLES, A. (2002), Seeing diplomacy through bankers' eyes: the World Bank, the Anglo-Iranian Oil Crisis, and the Aswan High Dam. Diplomatic History, 26(3), 397-4I 8.

STEPAN, A. (1971). The Military in Politics: Changing Patterns in Brazil. Princeton, NJ: Princeton University Press.

SWEDBERG, R. (1986) The doctrine of economic neutrality of the IMF and the World Bank. Journal of Peace Research, $\mathbf{2 3}(4)$, 377-90.

THACKER, S. (I999). The high politics of IMF lending. World Politics, 52(I), 38-75.

WEIS, M. (I993). Cold Warriors and Coups d'Etat: Brazilian-American Relations, 1945-1964. Albuquerque, NM: University of New Mexico Press.

WOODS, N. (2006) The Globalizers: The IMF, the World Bank and Their Borrowers. Ithaca, NY: Cornell University Press. 